\title{
BIOLOGICAL STUDIES OF LAELAPID PREDACIOUS MITES, ANDROLAELAPS CASALIS, BERLESE AND LAELAPS ASTRONOMICUS KOCH ON TWO FOOD TYPES UNDER THREE TEMPERATURE DEGREES
}

\author{
A.M. Mustafa(1), F.F. Shalaby (2), E.M.A. Yassin ${ }^{(1)}$, A. M. Khalil ${ }^{(1)}$, \\ Y.A.E. Eissa ${ }^{(1)}$ and Faten E. Shahata ${ }^{(1)}$ \\ (1) Plant Protection Research Institute, A.RC. Dokki, Giza, Egypt \\ (2) Econ. Entomology Dept., Fac. Agric. Benha Univ., Moshtohor
}

Received: Apr. 14, 2016

Accepted: Sep. 20,2016

\begin{abstract}
The present study aims to determine different biological aspects of the commonest soil predaceous mites, Androlaelaps casalis (Berlese) and Laelaps astronomicus Koch 1839 (Laelapidae) which were collected from untreated onion soil; at Qaha region, Qaluobia Governorate when reared on free living nematodes, Rhabditella muscicola Andrassy and the acarid mite, Tyrophagus putrescentiae (Schrank) at 20, 25 and $30{ }^{\circ} \mathrm{C}$ and $70 \%$ R.H. The study indicated that there were nonsignificant differences between the incubation period of A. casalis and $L$. astronomicus when fed on different diets. The female and male life-cycle of the two predacious mites when feed on free nematodes was significantly longer than those fed on $T$. putrescentiae. The pre-oviposition and post-oviposition periods of $A$. casalis and $L$. astronomicus were nonsignificantly affected by the prey types at the different temperatures. On the other hand, there were obviously differences when the mites fed during their ovipostion time on the same foods at the same temperatures. The study showed that the longevity of the $A$. casalis and L. astronomicus differed significantly when the adult female and male fed on the different diets at different tempertures. The current study also indicated that the feeding of the predacious mites $A$. casalis and $L$. astronomicus on nematode increased the number of deposited eggs by the mite female compared with those fed on the acarid mite.
\end{abstract}

Key words: Biology, control, predation, mites, Rhabditella muscicola nematode.

\section{INTRODUCTION}

Acari is considered a large economic group of arthropods, including different species live in soil and vegetative parts of plants. The roles played by these animals in nature are greatly important and vary from harmful to beneficial ones. The food sources for different groups of soil mites include nematodes, arthropods and plant roots (Inserra and Davis, 1983 and Zaher 1986). Several investigations have been directed towards utilizing predators and parasites as biological control agents. Beneficial soil mites, especially predatory species must be conserved in the field to promote a more stabilized pest as an natural balance, Lobbes and Schotten (1980). Owing to their numerical importance, the actinedid and gamasid mites have received more attention than other soil Acari. The majority of these species appear to be predators associated with small and immature stages of insects, mites, and nematodes under the soil surface (Karg, 1961 and Sardar and Murphy, 1987). Some of them may also feed on fungi and helps in control soil born fungi diseases (Ragusa and Zedan, 1985 and Ahmed 1998). Among the predatory mites, the mesostigmatid mites representing important component of the below ground food web, where they are generally considered to be predators feeding on small arthropods, worms and nematodes, Fouly and Abdel-Baky (2015).

The present work aims to study and throw some light on the biological aspects of two wide spread soil predacious laelapid mites, Laelaps astronomicus and 
Androlaelaps casalis when fed on free living nematodes, Rhabditella muscicola and the acarid mite, Tyrophagus putrescentiae at 20, 25 and $30{ }^{\circ} \mathrm{C}$ and $70 \%$ R.H.

\section{MATERIALS AND METHODS Collection and preparation of the predacious mites:}

Individuals belonging to the two predacious species of Androlaelaps casalis and Laelaps astronomicus were used in biological studies after being collected from normal untreated onion soil at Qaha region, Qaluobia Governorate. Mass rearing of predacious mites on the free living nematodes, Rhabditella muscicola Andrassy and the acarid mite, $T$. putrescentiae (Schrank) was maintained in the laboratory at 20,25 and $30{ }^{\circ} \mathrm{C}$ and $75 \pm 5 \%$ R.H.

\section{Study the effect of food source on the biological aspects of the two soil predacious mites:

Mass rearing of free living nematodes:}

For extracting free living nematodes, soil samples from clover fields in Qaluobia Governorate were put in Baermann funnels for 24 hours (Abou El-Sood, 1992). The extraction of free living nematode, Rhabditella muscicola was reared in Petri dishes containing slides of potatoes mixed with meat extraction. Petri-dishes were kept under natural laboratory conditions. By using camel hair brush, drops of food were added in rearing cells of the predatory mites as the main source of food. The collected individuals of both predators and prey nematodes were transferred to a covered glass Petri-dishes.

The bottom of the dish was covered with a layer of plaster of Paris and charcoal mixture $(9: 1) \quad(4.00 \mathrm{~mm})$ which was kept moist by adding drops of distilled water every couple days.

\section{Mass rearing of acarid mite:}

Individuals of the species of $T$. putrescentiae were obtained from clover soil at Qaluobia Governorate and reared on powder of yeast. For obtaining pure culture, adults of identified species were placed in rearing chamber which was cone plastic shape; it measured $(4 \times 4 \times 3 \mathrm{~cm}$.) and covered with soft plastic cover containing some pores for air supply. Dry yeast granules were added as food and few drops of water were added as a source of humidity. By using a camel brush, the movable stages of acarid mites were put in rearing cells of the tested mites.

\section{Rearing cages of Androlaelaps casalis and Laelaps astronomicus:}

The plastic rearing cages were constructed, each of a plastic cage $(1.5 \mathrm{~cm}$. in diameter and $2.0 \mathrm{~cm}$. height). The bottom was covered with a layer of a plaster of Paris and charcoal mixture according to Metwally et al., (1983). This bottom was kept moist, thus the relative humidity was maintained high by adding one or two drops of water every two days. A camel hair brush was used to transfer the mites to the cages. Observations were made twice a day. The plastic rearing cages were prepared in a way that they could be handled with a minimum of disturbance to the mites. They were stocked in trays or holders placed in carton boxes $(20 \times 15 \times 8 \mathrm{~cm})$. All biological studied data were subjected to two-way analysis of variance (ANOVA) and means were separated by Duncan's multiple range test (Duncan, 1955).

\section{RESULTS AND DISCUSSION}

This work was carried to study the effects of the free living nematode, $R$. muscicola and the acarid mite, $T$. putrescentiae on the biological aspects of the soil predacious mites, Androlaelaps casalis and Laelaspis astronomicus at 20,25 and $30{ }^{\circ} \mathrm{C}$. and $70 \%$ R.H

\section{Habitat and behavior:}

The soil predacious mite species, $A$. casalis (Berlese) and L. astronomicus are very active predators and move here and 
there; searching for their prey individuals. Individuals of these predacious mites were collected from soil (under onion plants at Qaluobia governorate) associated with acarid mites and other arthropods. Larvae of the tested predacious mites are changed to the successive stage without feeding, but the nymphal and adult stages are fed on moving immature stages of the acrid mite, $T$. putrescentiae, and free living nematodes. Individuals of these species were observed to more active in the cage. Members of these species preferred moderate humidity and rearing cages had to be supplied frequently with water droplets. Females of these predatory mites frequently preferred to deposit eggs singly into protected or unprotected places.

\section{Hatching:}

Eggs of $A$. casalis and $L$. astronomicus are whitish in color, then become creamy before hatching. Hatching process occurs through a longitudinal median slit.

\section{Moulting:}

A. casalis and $L$. astronomicus immatures when full grown entered a semiquiescent period during which, the mites stopped feeding. This period lasted about an hour after which individuals kept quiet, extended their chelicerae, palps and fore legs anterioly and hind legs posteriorly. Before moulting, the mite individuals made some successive movement beginning from propodosoma and ending in opisthosoma. The mite tried to free itself from the old exuvium by twisting movements and subsequently withdrew the forelegs and anterior part of the body to outside. Newly emerged individuals kept quiet near their old skin for a short period, and then started to move actively searching for their prey.

\section{Mating:}

The male and female accepted copulation immediately after emergence. In this process, the male approached female anteriorly and both vibrated their palps and touched it with forelegs. The male then moved around the female to reach her dorsum. This process lasted about 6-8 minutes for $L$. astronomicus and 9-11 minutes for $A$. casalis. After this, male crawled_underneath the female and clasped its body with the third and fourth pairs of legs, while male and female ventral surfaces were facing each other, nearly half body of the male projected behind the female. After copulation, both sexes separated and female accepted mating more than once in the two species.

\section{A. Androlaelaps casalis (Berlese) A. 1. Female Incubation period:}

It was clearly from Table (1) that there were no significant differences between the incubation period of the predacious mite, Androlaelaps casalis when fed on different diets (free living nematodes and the acarid mite, $T$. putrescentiae) at 3 different temperatures. This period reached 2.0, 1.8; $1.8,1.72$ and $1.69,1.57$ days for eggs at 20, 25 and $30^{\circ} \mathrm{C}$, respectively when females were fed on the both diets at different tempertures.

\section{Life-cycle:}

Results in Table (1) show that the life cycle period was significantly longer when mites fed on nematodes than that recorded by feeding on $T$. putrescentiae. It was 7.98 , 6.88 and 6.0 days when fed on free nematodes at 20,25 and $30 \stackrel{\circ}{\circ}$ for female, respectively. On the other hand, the mites reached maturity after $6.98,6.5$ and 5.5 days, respectively when females fed on acarid mite,

\section{Longevity:}

Concerning the adult longevity, statistical analysis of obtained data Table (1) pointed out that the longevity of the resulted females was significantly differed when the mite fed on different diets at different tempertures. It was $39.8,37.8 ; 37.0,34.0$ and 34.0, 31.0 when the adult female fed on the free living nematodes and $T$. putrescentiae at 20, 25 and $30^{\circ} \mathrm{C}$, respectively. 
Mustafa, et al.,

Table (1): Duration of developmental stages of Androlaelaps casalis when fed on two diets at 20,25 and $30^{\circ} \mathrm{C} \pm 2^{\circ} \mathrm{C}$ and $70 \pm 5 \%$ R.H.

\begin{tabular}{|c|c|c|c|c|c|c|c|}
\hline \multirow{3}{*}{\multicolumn{2}{|c|}{ Biological aspect }} & \multicolumn{2}{|c|}{$20 \stackrel{\circ}{ } \mathrm{C}$} & \multicolumn{2}{|c|}{$25 \stackrel{\circ}{\circ}$} & \multicolumn{2}{|c|}{$30^{\circ} \mathrm{C}$} \\
\hline & & \multicolumn{6}{|c|}{ Diet } \\
\hline & & A & B & A & B & A & B \\
\hline \multicolumn{2}{|c|}{ Incubation period } & $2.0 \pm 0.07$ & $1.8 \pm 0.07$ & $1.8 \pm 0.07$ & $1.7 \pm 0.04$ & $1.7 \pm 0.02$ & $1.57 \pm 0.9$ \\
\hline \multirow{2}{*}{ Life-cycle } & q & $7.98 \pm 0.1$ & $6.980 \pm 0.08$ & $6.88 \pm 0.0$ & $6.5 \pm 0.07$ & $6.0 \pm 0.04$ & $5.5 \pm 0.07$ \\
\hline & $\sigma^{\lambda}$ & $7.0 \pm 0.11$ & $6.0 \pm 0.06$ & $6.0 \pm 0.04$ & $5.8 \pm 0.04$ & $5.5 \pm 0.06$ & $5.0 \pm 0.07$ \\
\hline \multirow{2}{*}{ Longevity } & 우 & $39.8 \pm 0.8$ & $37.8 \pm 1.1$ & $37.0 \pm 0.7$ & $34.0 \pm 0.7$ & $34.0 \pm 0.7$ & $31.0 \pm 0.7$ \\
\hline & $0^{\pi}$ & $33.6 \pm 0.8$ & $32.5 \pm 1.0$ & $32.5 \pm 0.9$ & $30.5 \pm 0.8$ & $30.1 \pm 1.1$ & $28.2 \pm 0.1$ \\
\hline \multirow{2}{*}{ Life-span } & q & $47.8+2.6$ & $44.8 \pm 2.50$ & $43.9 \pm 2.4$ & $40.5 \pm 1.6$ & $40.0 \pm 2.4$ & $36.6 \pm 0.9$ \\
\hline & $\theta^{\lambda}$ & $40.5 \pm 1.3$ & $38.6 \pm 38.5$ & $38.6 \pm 1.7$ & $36.3 \pm 1.1$ & $35.8 \pm 1.3$ & $33.2 \pm 0.9$ \\
\hline
\end{tabular}

\section{Pre-oviposition, oviposition and post-oviposition periods :}

Results in Table (2) reported that the pre-oviposition and post-oviposition periods of the predacious mite, $A$. casalis of adult female not significantly changed with the feeding of the individuals on the different introduced diets (free nematodes and the acarid mite). On the other hand, there was obviously significantly differences when the mites during their oviposition time fed on the same both of foods; these periods took $35.92,34.08 ; 33.0, \quad 30.02$ and 30.0, $26.98 \pm 0.04$ days at 20,25 and $30{ }^{\circ} \mathrm{C}$, respectively.

\section{Fecundity:}

The resulted data in Table (2) clearly indicated that the feeding of $A$. casalis female on free living nematodes increased significantly the number of deposited eggs by the predators than when fed on the acarid mite,. The numbers of laid eggs were 39.8, 38.0; 44.0, 34.8 and 40.0, 31.8 when fed on nematodes and $T$. putrescentiae at 20,25 and $30 \stackrel{\circ}{\circ}$, respectively.

\section{Life-span:}

According to data presented in Table (1), the life span of $A$. casalis lasted $47.8,44.8$ \& $43.9,40.5$ and $40.04,36.6$ days when the mites were fed on nematodes and $T$. putrescentiae at 20,25 and $30{ }^{\circ} \mathrm{C}$., respectively.

\section{A.2. Male}

\section{Incubation period:}

Results in Table (3) indicate that the incubation period of $A$. casalis male lasted $2.0,1.8 ; 1.8,1.72$ and $1.69,1.57$ days when fed on the two diets at 20,25 and $30{ }^{\circ} \mathrm{C}$, respectively.

\section{Life-cycle:}

The male of the predacious mite, $A$. casalis completed their life- cycle in 7.0 and 6.01 days at $20{ }^{\circ} \mathrm{C}$ when fed on both free nematodes and the acarid mite, $T$. putrescentiae, respectively. However, these periods changed to 6.0 and 5.8 days at 25 ${ }^{\circ} \mathrm{C}$ and 5.5 and 5.0 days at $30{ }^{\circ} \mathrm{C}$, respectively. 
Table (2): Longevity and fecundity of the predacious mites, Androlaelaps casalis adult female when fed on two diets at different tempertures.

\begin{tabular}{|c|c|c|c|c|c|c|}
\hline \multirow{3}{*}{$\begin{array}{l}\text { Biological } \\
\text { aspect }\end{array}$} & \multicolumn{2}{|c|}{$20^{\circ} \mathrm{C}$} & \multicolumn{2}{|c|}{$25^{\circ} \mathrm{C}$} & \multicolumn{2}{|c|}{ 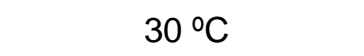 } \\
\hline & \multicolumn{6}{|c|}{ Diet } \\
\hline & A & B & A & $B$ & $A$ & $B$ \\
\hline Pre-ovip.period & $1.98 \pm 0.11$ & $1.84 \pm 0.11$ & $1.84 \pm 0.2$ & $2.04 \pm 0.2$ & $2.08 \pm 0.27$ & $1.94 \pm 0.11$ \\
\hline Ovipos. period & $35.92 \pm 0.1$ & $34.08 \pm 0.3$ & $33.0 \pm 0.07$ & $30.02 \pm 0.1$ & $30.0 \pm 0.14$ & $26.98 \pm 0.4$ \\
\hline $\begin{array}{l}\text { Post-ovip. } \\
\text { period }\end{array}$ & $1.94 \pm 0.09$ & $1.88 \pm 0.13$ & $1.98 \pm 0.1$ & $1.98 \pm 0.1$ & $2.04 \pm 0.13$ & $1.9 \pm 0.12$ \\
\hline Fecundity & $39.8 \pm 1.1$ & $38.0 \pm 0.7$ & $44.0 \pm 0.7$ & $34.8 \pm 0.4$ & $40.0 \pm 0.7$ & $31.8 \pm 0.44$ \\
\hline
\end{tabular}

$A=$ Free living nematodes

$\mathrm{B}=$ T. putrescentiae

Table (3): Duration of developmental stages of Laelaps astronomicus when fed on two diets at 20,25 and $30^{\circ} \mathrm{C} \pm 2^{\circ} \mathrm{C}$ and $70 \pm 5 \%$ R.H.

\begin{tabular}{|c|c|c|c|c|c|c|c|}
\hline \multirow{3}{*}{\multicolumn{2}{|c|}{ Biological aspect }} & \multicolumn{2}{|c|}{$20 \stackrel{\circ}{C}$} & \multicolumn{2}{|c|}{$25 \stackrel{\circ}{C}$} & \multicolumn{2}{|c|}{$30 \stackrel{\circ}{C}$} \\
\hline & & \multicolumn{6}{|c|}{ Diet } \\
\hline & & $A$ & $B$ & $A$ & B & A & B \\
\hline \multicolumn{2}{|c|}{ Incubation period } & $1.8 \pm 0.04$ & $1.7 \pm 0.07$ & $1.6 \pm 0.02$ & $1.6 \pm 0.07$ & $1.5 \pm 0.07$ & $1.42 \pm 0.04$ \\
\hline \multirow{2}{*}{ Life-cycle } & q & $7.0 \pm 0.07$ & $6.1 \pm 0.20$ & $5.9 \pm 0.11$ & $5.5 \pm 0.07$ & $5.0 \pm 0.04$ & $4.78 \pm 0.11$ \\
\hline & $\sigma^{\lambda}$ & $6.4 \pm 0.05$ & $5.4 \pm 0.10$ & $5.1 \pm 0.08$ & $4.6 \pm 0.07$ & $4.0 \pm 0.08$ & $4.22 \pm 0.09$ \\
\hline \multirow{2}{*}{ Longevity } & q & $35.4 \pm 1.1$ & $33.0 \pm 0.7$ & $32.0 \pm 0.7$ & $31.0 \pm 1.7$ & $29.8 \pm 0.4$ & $26.0 \pm 0.7$ \\
\hline & $\sigma^{\lambda}$ & $32.9 \pm 1.1$ & $30.5 \pm 0.8$ & $28.9 \pm 1.2$ & $27.8 \pm 0.9$ & $26.5 \pm 0.25$ & $21.5 \pm 0.6$ \\
\hline \multirow{2}{*}{ Life-span } & q & $42.6 \pm 2.6$ & $39.1 \pm 1.4$ & $38.0 \pm 1.3$ & $36.5 \pm 0.9$ & $34.0 \pm 0.9$ & $30.81 \pm 1.6$ \\
\hline & $\hat{0}$ & $39.3 \pm 1.4$ & $36.0 \pm 0.2$ & $34.0 \pm 0.6$ & $34.4 \pm 1.8$ & $30.5 \pm 0.9$ & $25.7 \pm 0.8$ \\
\hline
\end{tabular}

$A=$ Free living nematodes

$\mathrm{B}=$ T. putrescentiae

\section{Longevity:}

The current results denoted that, when the male of the predator, $A$. casalis were fed on the same previously mentioned diets at the same laboratory conditions, the duration of the longevity took $33.6 \& 32.5 ; 32.5 \&$
30.5 and $30.1 \& 28.2$ days at 20,25 and 30 ${ }^{\circ} \mathrm{C}$, respectively (Table 3 ).

\section{Life-span:}

The life-span of the predacious mite, $A$. casalis male individuals when fed on two diets at 20,25 and $30{ }^{\circ} \mathrm{C}$ and $70 \%$ R.H., 
differed significantly according to the type of introduced rearing diets as in case of females (Table 3 ). The life-span took 40.5 , $38.61 \& 38.6,36.3$ and $35.8,33.2$ days, respectively.

\section{B. Laelaps astronomicus Koch B.1- Female Incubation period:}

The obtained results in Table (3) show that the differences between incubation periods of eggs of the predacious mite, $L$. astronomicus when reared on free nematodes and $T$. putrescentiae at different temperatures were non-significant. This period elapsed $1.82 \& 1.7 ; 1.61 \& 1.6$ and $1.5 \& 1.42$ days at 20,25 and $30{ }^{\circ} \mathrm{C}$, respectively

\section{Life cycle:}

As for the life cycle of the predacious mite, L. astronomicus females, the current tabulated data in Table (3) shows that female life cycle when rearing on nematodes was significantly longer than those recorded by rearing on $T$. putrescentiae. The life cycle of this mite took $7.0 \& 6.06 ; 5.92 \& 5.5$ and $4.98 \& 4.78$ days when the female fed on nematodes and the acarid mite at 20, 25 and $30 \stackrel{\circ}{\circ}$, respectively.

\section{Longevity:}

Concerning the adult longevity of female, data presented in Table (3) pointed out that the longevity of the resulted females differed significantly when the adults $L$. astronomicus were fed on the different diets at different temperatures. The adult life time averaged $35.4 \& 33.0 ; 32.0 \& 31.0$ and $29.8 \& 26.0$ days when the females were fed on nematodes and $T$. putrescentiae at 20, 25 and $30{ }^{\circ} \mathrm{C}$, respectively.

\section{Life-span:}

According to the obtained data, the lifespan of the predacious mite, $L$. astronomicus when fed on free living nematodes and $T$. putrescentiae at 20, 25 and $30{ }^{\circ} \mathrm{C}$., the female's life-span varied significantly according to the type of introduced rearing diets (Table 3 ). The lifespan lasted $42.6 \& 39.1 ; 38.0 \& 36.5$ and $34.01 \& 30.81$ days, respectively

\section{Pre-oviposition, ovipostion and post-ovipostion periods:}

Results in Table (4) denoted that the preoviposition and post-oviposition periods of the predacious mite, $L$. astronomicus did not vary significantly when fed on two diets (nematodes and T. putrescentiae) at 20, 25 and $30 \stackrel{\circ}{\circ}$, being about 2 days. On the other hand, the effect of both diets and temperature was very obvious on the oviposition period of this predator. This period lasted $31.0 \& 28.95$ at $20{ }^{\circ} \mathrm{C} ; 28.22$ \& 29.94 at $25{ }^{\circ} \mathrm{C}$ and $26.04 \& 22.0$ days at 30 ${ }^{\circ} \mathrm{C}$, respectively.

\section{Fecundity:}

Results in Table (4) indicate that the total deposited eggs of the predacious mite, $L$. astronomicus female was 35.0 \& $33.0 ; 37.8$ $\& 30.0$ and 34.0 \& 27.0_eggs when the mite were fed on free nematodes and $T$. putrescentiae mite at 20,25 and $30 \stackrel{\circ}{\circ}$, respectively.

\section{B.2- Male Incubation period:}

The incubation period of eggs which gave rise to male individuals was the same as that of females and recorded $1.82 \& 1.7$; $1.61 \& 1.6$ and $1.5 \& 1.42$ days at 20,25 and $30 \stackrel{\circ}{\circ}$, when the mites were fed on both nematodes and the acarid phytophagous mite, respectively.

\section{Life-cycle:}

Concerning the life-cycle of $L$. astronomicus the current tabulated data in Table (3), the life-cycle of males lasted 6.4 \& $5.42 ; 5.11 \& 4.6 \& 4.0$ and 4.2 days when individuals were fed on the same two types of food at the same laboratory conditions, respectively. 
Table (4): Longevity (in days) and fecundity (total deposited eggs) of predacious mite, Laelaps astronomicus female when fed on two diets at three temperature degrees.

\begin{tabular}{|c|c|c|c|c|c|c|}
\hline \multirow{3}{*}{ Biological aspect } & \multicolumn{2}{|c|}{$20 \stackrel{\circ}{C}$} & \multicolumn{2}{|c|}{$25^{\circ} \mathrm{C}$} & \multicolumn{2}{|c|}{$30 \stackrel{\circ}{\circ} \mathrm{C}$} \\
\hline & \multicolumn{6}{|c|}{ Diet } \\
\hline & A & B & A & B & A & B \\
\hline Pre-ovi. period & $1.8 \pm 0.19$ & $1.8 \pm 0.19$ & $1.9 \pm 0.25$ & $1.9 \pm 0.19$ & $2.0 \pm 0.05$ & $1.9 \pm 0.23$ \\
\hline Oviposition period & $31.0 \pm 0.4$ & $29.0 \pm 0.3$ & $28.2 \pm 0.6$ & $29.9 \pm 0.30$ & $26.0 \pm 0.2$ & $22.0 \pm 0.14$ \\
\hline Post-ovi. period & $1.9 \pm 0.1$ & $2.0 \pm 0.1$ & $2.0 \pm 0.1$ & $1.9 \pm 0.09$ & $2.1 \pm 0.3$ & $2.0 \pm 0.01$ \\
\hline Fecundity & $35.0 \pm 0.7$ & $33.0 \pm 0.7$ & $37.8 \pm 1.1$ & $30.0 \pm 0.14$ & $34.0 \pm 0.7$ & $27.0 \pm 0.7$ \\
\hline
\end{tabular}

\section{Longevity:}

Results in Table (3) show that the longevity period of $L$. astronomicus adult males durated $32.9 \& 30.5 ; 28.9 \& 27.8$ and $26.5 \pm 0.25 \& 21.5$ days, respectively when reared at the same previously mentioned conditions.

\section{Life-span:}

As shown in Table (3) the mite life span of $L$. astronomicus male when fed on different diets (nematodes and $T$. putrescentiae) at 20,25 and $30{ }^{\circ} \mathrm{C}$., differed significantly according to the type of introduced diets. This period took 39.3 \& 36.02; 34.0 \& 34.4 and $30.5 \& 25.7$ days, respectively. Generally, as in most mesostigmatid mites, the predacious mites, $A$. casalis and $L$. astronomicus females lived for a longer time than males.

Similar results were obtained by Imbriani and Mankau (1983) observed voracious feeding by a mesostigmatid mite Lasioseius sculpatus on Aphelenchus avenae and Cephalobus sp. In culture, increased population of mite resulted in a significant decline of Aphelenchus avenae. Observation of Bilgrami (1994) on $T$. putrescentiae revealed that these mites are predacious on many species of plant and soil nematodes belonging to three trophic categories viz., saprophagous, plant parasitic and predacious nematodes. Mites preferred second-stage juveniles of plant parasitic nematodes but predacious nematodes resisted predation comparatively better than others. In harmony with the presented results, also Ezz El-Dein (2003) studied the effect of different diets on the biological aspects of the two predacious mites, Laelaspis imitatus and Laseioseus aegypticus especially developmental period, life-cycle and the reproductive rate. The life cycle significantly differed according to the food types which could be arranged in a descending order as follows: collembola, $T$. putrescentiae and nematode at $25 \stackrel{\circ}{\circ}$ and $T$. putrescentiae then free nematode at $35^{\circ} \mathrm{C}$, respectively. The mite's fed on nematode at 25 드 laid more eggs, while feeding on collembola resulted in the lowest fecundity. On the other hand, Mowafi (2005) noticed that the duration of Chiropturopoda bakeri Zaher and Afifi development stages, reproduction and feeding habits were greatly affected by prey species. The nematodes (free-living) $R$. scanica Allegen and plant parasitic nematodes Meloidogyne incognita Kofoid \& White were more suitable than housefly larvae for increasing reproductive 
potentiality of $C$. bakeri at $25{ }^{\circ} \mathrm{C}$. Fouly and Abdel-Baky (2015) reported that the laelapid mite, Cosmolaelaps qassimensis life cycle and life span were significantly shorter when fed on, $T$. putrescentiae followed by Caloglyphus rodriguez Samsinak and then egg masses of the root-knot nematode, Meloidogyne incognita Chitwood as food sources under laboratory conditions of $26 \stackrel{\circ}{\circ}$ and $70 \%$ R.H.

\section{REFERENCES}

Abou El-Sood, A. B . (1992). Ecological and taxonomical studies on nematodes in certain Governorates of Egypt Ph.D. Thesis. Fac. Agric., Al-Azhar Univ., pp. 252.

Ahmed, Wafaa O.(1998). Biological studies on some species of mesostigmatic mites with species reference to their chemical analysis together with preys. Ph. D.Thesis, Fac. Agric., Cairo Univ., pp. 299.

Bilgrami, A. L. (1994). Predatory behavior of a nematode feeding mite, (Tyrophagus putrescentiae

(Sarcoptiformes: Acaridae). Fudam. Appl. Neamtol. 17(4):293-297.

Duncan, D. B. (1955). Multiple range multiple $\mathrm{F}$ test . Biometrics, 11: 1- 14

Ezz El-Dein. S. A. (2003). Studies on some soil predacious mites associated with some field crops. M. Sc. Thesis, Fac. Sci., Al-Azhar Univ., (Girls), 148 pp.

Fouly, A. H. and N. F. Abdel-Baky (2015). Influence of prey types on the biological characteristics of Cosmolaelaps qassimensis (Acari: Laelapidae). Journal of Entomology, 12 (1): 21-29.

Imbriani, J. I. and R. Mankau (1983). Studies on Lasioscius sculpatus, a mesostigmatid mite predacious on nematodes. J. Nematol., 15: 523 - 528.

Inserra, R.V. and D.W. Davis (1983). Hypoaspis near aculeifer. A mite predacious on root-knot and cyst nematodes. J. Nematol., 15: 324-325.

Karg, V. W. (1961). Okologisch Untersuchungen von edaphischen Gamasiden(Acarina: Parasitioformes).Pedobiologia, 1: 77- 98.

Lobbes, P. and C. Schotten (1980). Capacity of increase of the soil mite Hypoaspis aculeifer Canestrini (Mesostigmata: Laelapidae). Zeitschrift fur Angewandte Entomologie, 90: 9-22.

Metwally, A. M., M. Abou-El-Naga and G. A. Ibrahim (1983). Biological studies on Hypoaspis miles (B.) (Acarina: Laelapidae) . Proc. $5^{\text {th }}$ Arab. Pesticide Conf. Tanta Univ., (3): 336 - 346.

Mowafi, M. H. (2005). Biological studies and feeding habits of the mite species Chiropturopoda bakeri Zaher and Afifi (Acarina: Uropodidae). Egypt. J. Biological Pest Control, 15 (2): 97-98.

Ragusa, S. and M. A. Zedan (1985). The effects of food from plant and animal sources on the predacious mite Hypoaspis aculeifer (Canestrini) (Parasitiformes,Dermanessidae).Redia, 31(69):481-487.

Sardar, M. A. and P. W. Murphy (1987). Feeding tests of grass land soil inhabiting Gamasine Predators. Acarologia, 28 (2): 117-121.

Zaher, M.A. (1986). Predacious and nonpredacious mites in Egypt (Nile Valley and Delta).pL. 480 Prog. USA Project No. EGARS-30. Grant No. FG-EG-139. 
دراسات بيولوجية على الاكاروسات المفترسة من ذوات الثغر المتوسط :

\section{Laelaps astronomicus Koch ، Androlaelaps casalis Berlese}

\section{عند التظذية على نوعين من الغذاء تحت ثلاث درجات حرارة}

عادل محمود مصطفى(1) ، فوزى فائق شلبى(2) ، عصام محمد عبدالسلام ياسين(1) ،

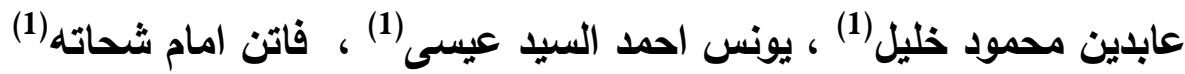

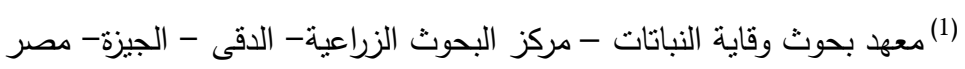

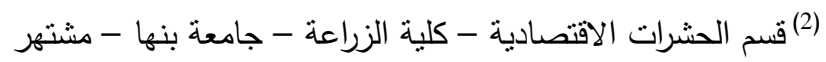

Rhabditella muscicola أجريت هذه الدراسـة المعليـة لمعرفة تاثير كـلا من النيماتودا الحرة المعيشـة والاكـاروس الاكاريدى Tyrophagus putrescentiae على المظـاهر البيولوجيـة للاكاروسين المفترسين Laelaspis astronomicus Koch و Androlaelaps casalis (Berlese)

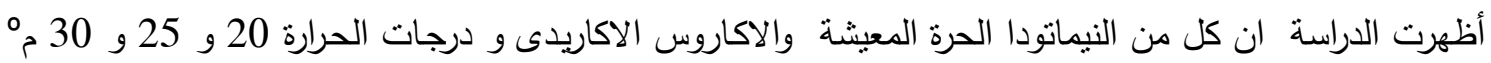

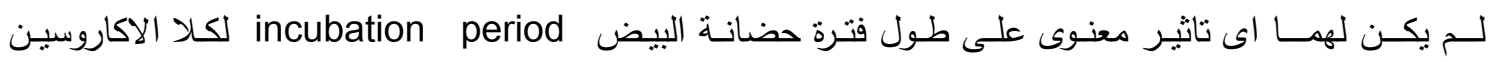

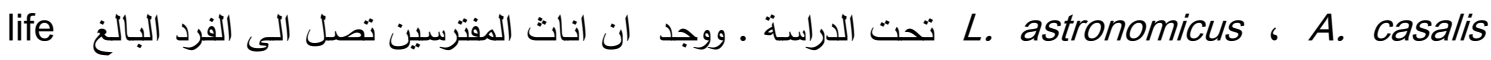

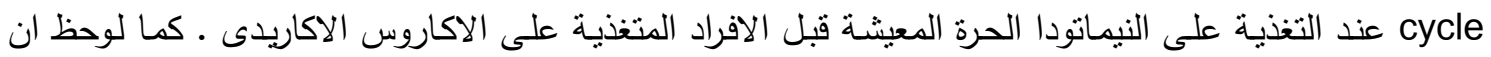

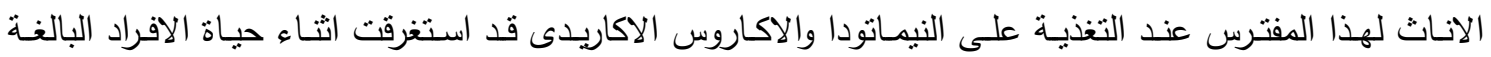
Longevity الذكور عند نفس الظروف. ومن خلال النتائج المتحصل عليها اثثاء الدراسة اتضح ان نوع الغذاء ودرجات الحرارة المستخدمة لها يؤثران ناثثرا معنويا على طول فترة قبل وضع البيض وفترة بعد وضع البيض والتى نراوحت حول

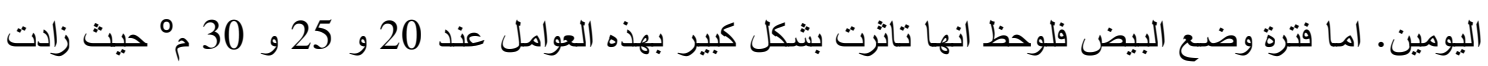

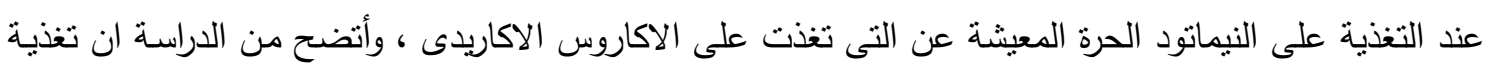

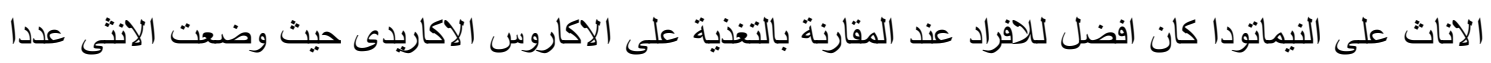

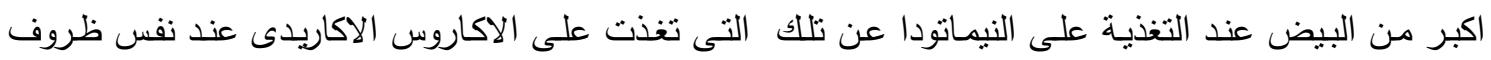
التجربة.

E-mail: Muj-protec@agr.menofia.edu.eg 
Mustafa, et al., 